\title{
Successful treatment of relapsed/refractory B-Acute lymphoblastic leukemia with Inotuzumab ozogamicin after blinatumomab failure
}

\author{
Sergey N. Bondarenko, Anna G. Smirnova, Ivan S. Moiseev, Bella I. Ayubova, Elena V. Babenko, Ildar M. Barkhatov, \\ Tatiana L. Gindina, Inna V. Markova, Alexander D. Kulagin, Boris V. Afanasyev \\ RM Gorbacheva Research Institute of Pediatric Oncology, Hematology and Transplantation, Pavlov University, St. Petersburg, \\ Russia
}

Dr. Sergey N. Bondarenko, RM Gorbacheva Research Institute of Pediatric Oncology, Hematology and Transplantation, Pavlov University, L. Tolstoy St. 6-8, 197022 ,

St. Petersburg, Russia
Phone: +7 (812) 33862372

E-mail: dr.sergeybondarenko@gmail.com

Citation: Bondarenko SN, Smirnova AG, Moiseev IS et al. Successful treatment of relapsed/refractory B-Acute lymphoblastic leukemia with Inotuzumab ozogamicin after blinatumomab failure. Cell Ther Transplant 2020; 9(2): 67-70.

\section{Summary}

Blinatumomab, a bispecific T-cell engaging CD3-CD19 antibody, is highly effective in patients with relapsed/ refractory $(\mathrm{R} / \mathrm{R})$ B-cell acute lymphoblastic leukemia (ALL) even after allogeneic hematopoietic stem cell transplantation (allo-HSCT). However, patients who failed with Blina have a dismal outcome. Inotuzumab ozogamicin is one of the therapeutic options after blinatumomab failure. We report a young man who exhibited bone marrow (BM) relapse of B-ALL following haploidentical stem cell transplantation (haplo-HSCT). Remission was not achieved after Blinotumomab treatment, thus Inotuzumab was administered. A complete remission with no signs of minimal residual disease was achieved after a single cycle of Inotuzumab. The second haplo-HSCT from another donor was successful.

\section{Conclusion}

The present case demonstrate an opportunity of successful inotuzumab therapy after failure of allo-HSCT and blinotumomab treatment.

\section{Keywords}

Hematopoietic stem cell transplantation, allogeneic, acute lymphoblastic leukemia, Blinotumomab, Inotuzumab ozogamicin, relapsed/refractory.

\section{Introduction}

Haploidentical HSCT is the established option for high-risk acute lymphoblastic leukemia in absence of HLA-identical donors [1]. However, relapse after haplo-HSCT has limited options for cure [2]. Second transplantation could be effective in patients that achieved remission [3]. The currently available immunotherapies, e.g., blinatumomab, a bispecific T-cells engager (BITE) antibody, or conjugate antibody inotuzumab ozogamicin have provided curative strategy in some patients to achieve remission before second haploHSCT with acceptable toxicity. Blinatumomab and inotu- zumab ozogamicin demonstrate comparable CR rates, with a trend for blinatumomab administration in the setting of low-level residual disease, or lower marrow blast percentages without CNS involvement. Inotuzumab ozogamicin is effective regardless of blast counts $[4,5]$. Despite these encouraging results, patients refractory to immunotherapy have poor prognosis [6].

\section{Case description}

A young man aged 15 years old was diagnosed with B-ALL, isolated marrow involvement, in September, 2015. Cytogenetic test revealed 53XY, no molecular abnormalities found. 
The patient was treated according to the National $A L L$ MB2015 protocol, and morphological remission was reached after first induction cycle. The protocol was completed in December 2017. BM relapse with the same karyotype was documented 8 months later, in August 2018. The treatment proceeded by $A L L-R E Z-B F M-2002$ protocol. Second morphologic remission was achieved after the first cycle. In December 2018, the patient was referred to the transplant center, and multicolor flow cytometry of leukocytes showed minimal residual disease at $1.8 \%$. HLA-identical donor search was unsuccessful, and, therefore, allo-HSCT from haploidentical father was performed 11.12.2018. Myeloablative conditioning regimen included Fludarabine, Treosulfan and Tiotepa. GvHD prophylaxis was performed with ex vivo TCR $\alpha \beta$ depletion. Engraftment with complete donorchimerism and MRD negativity was reached at day+11. However, lymphopenia of moderate to severe grade persisted over this period (Fig. 1).

In May 2019, bone marrow (BM) examination has revealed $64 \%$ of blasts with CD45dim/CD19+/CD10+/CD34+/ CD38-/CD22+/CD20- phenotype. The indexes of cerebrospinal fluid were normal, no extramedullar lesions were found. Blinatumomab was administered as a prolonged 4-week infusion after a pre-phase with cyclophosphamide treatment at a dose of $200 \mathrm{mg} / \mathrm{kg}$. The therapy was well tolerated, in absence of non-hematologic toxicity. BM examination revealed $89 \%$ of blasts with CD $45 \mathrm{dim} / \mathrm{CD} 19+/ \mathrm{CD} 10+/$ CD34-/CD38+/CD22+/CD20- phenotype ten days later. Inotuzumab ozogamicin was administered at the doses of $1.8,0.8$ and $0.5 \mathrm{mg} / \mathrm{m}^{2}$ weekly. Inotuzumab treatment was

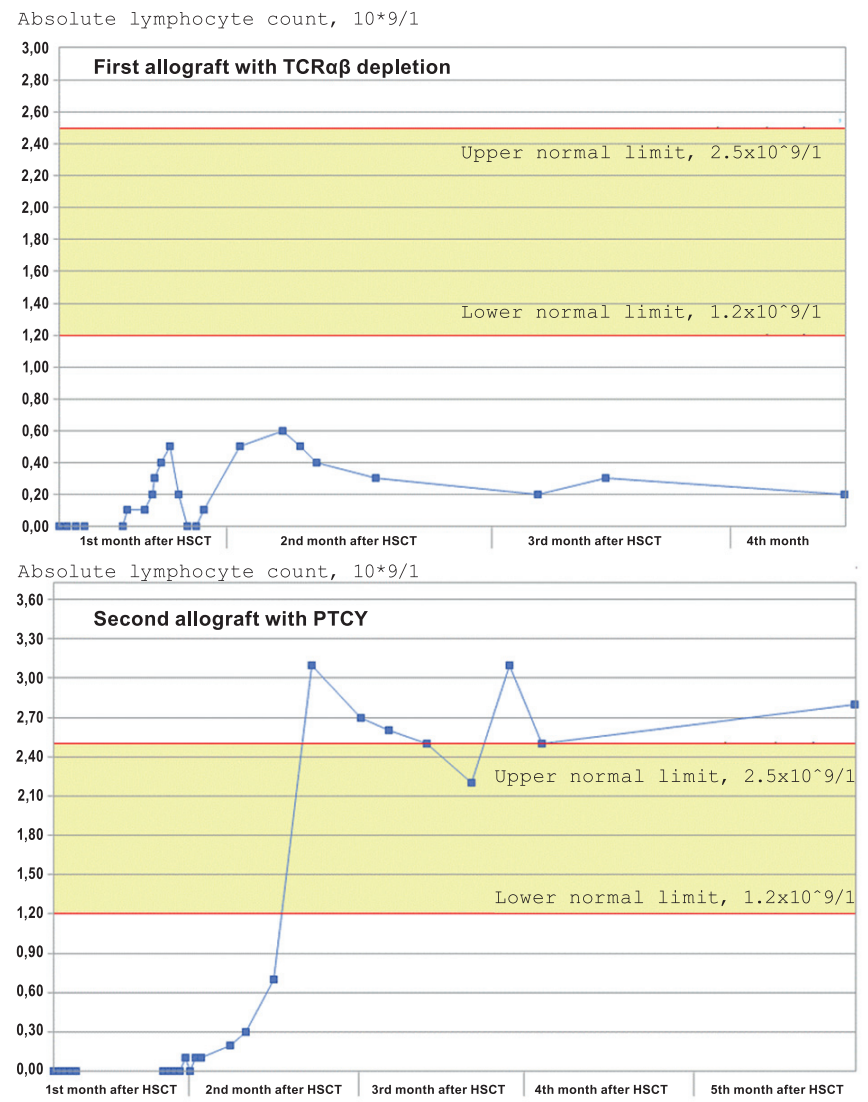

Figure 1. Blood lymphocyte counts: time course following $1^{\text {st }}$ and $2^{\text {nd }}$ transplant (for details see text) well tolerated, without non-hematologic toxicity, thrombocytopenia grade 2 and neutropenia grade 4 proved to be reversible. Complete BM remission was achieved, and MRD was negative.

Allogeneic stem cell transplantation from haploidentical mother was performed 05.09.2019., four weeks after finishing Inotuzumab therapy. Conditioning regimen with reduced toxicity included Fludarabine and Busulfan $10 \mathrm{mg} / \mathrm{kg}$. GvHD prophylaxis was performed with posttransplant cyclophosphamide, tacrolimus, mycophenolate mofetil. Engraftment was documented on the day +23 , with complete donor chimerism and MRD negativity. No signs of sinusoidal occlusive syndrome were observed, and no acute GvHD occurred. Tacrolimus was discontinued by D+100. After 9 months of follow up, the patient is in complete MRD-negative remission with mild cGvHD, without any systemic medications.

\section{Discussion}

Haploidentical hematopoietic stem cell transplantation with ex vivo TCR $\alpha \beta$ depletion is a novel approach aimed to reduce graft failure, graft-versus-host disease (GvHD) rate, and non-relapse mortality (NRM) in patients lacking HLA-indentical donor. However, high relapse rate and delayed immune reconstitution remain the principal disadvantages of this method [7]. Blinatumomab is a bispecific T-cell engager (BiTE) antibody designed to link T cells and CD19-positive $\mathrm{B}$ cells, which allows the patient's endogenous T cells to recognize and eliminate CD19-positive ALL blasts [8]. Blinotumomab is highly effective in R/R ALL patients with $69 \%$ of complete remission (CR), or with incomplete hematologic recovery achieved even after alloHSCT [4, 9-10]. Jabbour et al. reported 68 patients with R/R B-cell ALL with blinatumomab failure, 38 (56\%) of them was initially refractory to this treatment [11]. The mechanism of refractory disease is not clear. Among the blinatumomab-refractory patients, only one patient lost CD19 expression, and a decrease in CD19 expression was found in two cases. Among the relapsed patients who initially responded, four patients have lost CD19 expression. After blinatumomab failure, the overall response rate to inotuzumab ozogamicin was $77 \%(10 / 13)$.

Another mechanism of resistance may be a lineage switch after blinatumomab treatment reported in several cases [12, 13]. Functional immune system is also required for benefit of blinatumomab [14]. The possible reason of blinatumomab failure in our case was low absolute lymphocyte count was $0.9 \times 10^{9}$, with $35 \%$ of $\mathrm{CD} 3+$ cells that are required for blinatumomab action (Fig. 1). Along with quantitative abnormalities, the repertoire of T-cells is significantly skewed after TCR $\alpha \beta$ depletion, than after conventional prophylaxis [15]. Inotuzumab ozogamicin is a monoclonal antibody conjugated to cytotoxic agent, it works regardless tumor burden [16]. It doesn't require lymphocytes to mediate its pharmacological activity. Further accumulation of clinical data should facilitate better decision-making for different modes of immunotherapy in R/R B-cell ALL.

\section{Conflict of interest}

None declared. 


\section{References}

1. Santoro N, Ruggeri A, Labopin M, Bacigalupo A, Ciceri F, Gülbaş Z, Huang H, Afanasyev B, Arcese W et al. Unmanipulated haploidentical stem cell transplantation in adults with acute lymphoblastic leukemia: a study on behalf of the Acute Leukemia Working Party of the EBMT. Journal of Hematology \& Oncology. 2017; 10:113.

2. Gökbuget N, Dombret H, Ribera JM, Fielding AK, Advani A, Bassan R, Chia V, Doubek M, Giebel S, Hoelzer D et al. International reference analysis of outcomes in adults with B-precursor Ph-negative relapsed/refractory acute lymphoblastic leukemia. Haematologica. 2016;101(12):1524-1533.

3. Kozhokar P, Paina O, Frolova A, Rakhmanova Zh, Borovkova A, Semenova E, Osipova A, Ekushov K, Ovechkina V, Babenko E, Vitrishchak A, Smirnov B et al. Efficiency of second allogeneic HSCT in the children with acute leukemias with relapses after first transplantation. Cell Ther Transplant. 2019; 8(4): 33-40.

4. Kantarjian H, Stein A, Gökbuget N, Fielding A, Schuh A, Ribera JM, Wei A, Dombret H, Foà R, Bassan R et al. Blinatumomab versus chemotherapy for advanced acute lymphoblastic leukemia. N Engl J Med. 2017; 376(9): 836-847.

5. Kantarjian H, De Angelo D, Stelljes M, Liedtke M, Stock W, Gökbuget N, O'Brien S, Jabbour E, Wang T, Liang et al. Inotuzumab ozogamicin versus standard of care in relapsed or refractory acute lymphoblastic leukemia: Final report and long-term survival follow-up from the randomized, phase 3 INO-VATEstudy. Cancer. 2019;125(14): 2474-2487.

6. Jabbour E, O'Brien S, Ravandi F, Kantarjian H. Monoclonal antibodies in acute lymphoblastic leukemia. Blood. 2015;125(26):4010-4016.

7. Locatelli F, Merli P, Pagliara D, Li Pira G, Falco M, Pende D, Rondelli R, Lucarelli B, Brescia L, Masetti R et al. Outcome of children with acute leukemia given HLA-haploidentical HSCT after $\alpha \beta$ T-cell and B-cell depletion. Blood. 2017;130:677-685.

8. Kantarjian H, Stein A, Gökbuget N, Fielding A, Schuh A, Ribera J, Wei A, Dombret H, Foà R, Bassan R. et al. Blinatumomab versus chemotherapy for advanced acute lymphoblastic leukemia. N Engl J Med 2017;376:836-847.

9. Stein AS, Kantarjian H, Gökbuget N, Bargou R, Litzow MR, Rambaldi A, Ribera J-M, Zhang A, Zimmerman Z, Zugmaier G, Topp MS et al. Blinatumomab for acute lymphoblastic leukemia relapse after allogeneic hematopoietic stem cell transplantation. Biol Blood Marrow Transplant. 2019; 25(8):1498-1504.

10. Bondarenko S, Parovichnikova E, Maschan A, Baranova O, Shelekhovas T, Doronin V, Mel'nichenko V, Kaplanov K, Uspenskaya O, Sokolov A et al. Blinatumomab in the treatment of acute lymphoblastic leukemia: Russian Multicenter Clinical Trial. Clinical Oncohematology. 2019;12(2):145-153 (In Russian).

11. Jabbour E, Düll J, Yilmaz M, Khoury J, Ravandi F, Jain N, Einsele H, Garcia-Manero G, Konopleva M, Short N et al.
Outcome of patients with relapsed/refractory acute lymphoblastic leukemia after blinatumomab failure: no change in the level of CD19 expression. Am J Hematol. 2018; 93:371374.

12. Rayes A, McMasters R, O'Brien M. Lineage switch in MLL-rearranged infant leukemia following CD19-directed therapy. Pediatr Blood Cancer. 2016; 63(6):1113-1115.

13. Duffner U, Abdel-Mageed A, Younge J, Tornga C, Scott K, J Staddon J, Elliott K, Stumph J, Kidd P et al. The possible perils of targeted therapy. Leukemia. 2016;30(7):1619-1621.

14. Schultz L, Gardner R. Mechanisms of and approaches to overcoming resistance to immunotherapy. Hematology Am Soc Hematol Educ Program. 2019 (1): 226-232.

15. Zvyagin IV, Mamedov IZ, Tatarinova OV, Shugay M, Sycheva AL, Kasatskaya SA, Lebedev YB, Chudakov DM, Tatarinova OV, Kurnikova EE et al. Tracking T-cell immune reconstitution after TCRaß/CD19-depleted hematopoietic cells transplantation in children. Leukemia. 2017; 31(5):1145-1153.

16. Markova IV, Bondarenko SN, Paina OV, Aubova BI, Kozhokar PV, Frolova AS, Barkhatov IM, Babenko EV, Alyanskii AA, Ekushov KA, Gindina TL, Semenova EV, Moiseev IS, Zubarovskaya LS, Afanasyev BV. Features of response to blinatumomab and inotuzumab ozogamicin therapy in patients with relapse/refractory B-cells acute lymphoblastic leukemia in real clinical practice. Cell Ther Transplant. 2019; 9(1):47-52. 


\section{Успешное применение инотузумаба озогамицина при лечении резистентного В-клеточного острого лимфо- бластного лейкоза, рефрактерного к блинотумомабу}

Сергей Н. Бондаренко, Анна Г. Смирнова, Иван С. Моисеев, Белла И. Аюбова, Елена В. Бабенко, Ильдар М. Бархатов, Татьяна Л. Гиндина, Инна В. Маркова, Александр Д. Кулагин, Борис В. Афанасьев

НИИ детской онкологии, гематологии и трансплантологии им. Р. М. Горбачевой, Первый Санкт-Петербургский государственный медицинский университет им. акад. И. П. Павлова, Санкт-Петербург, Россия

\section{Резюме}

Блинатумомаб, биспецифичное моноклональное антитело, активирующее Т-клетки пациента при связывании CD3 на поверхности Т-клеток и CD19 на поверхности В-лимфобластов, высоко эффективен при лечении резистентных В-клеточных острых лимфобластных лейкозов (В-ОЛЛ) в том числе при возникновении рецидива после аллогеннной трансплантации гемопоэтических стволовых клеток крови (алло-ТГСК). Однако прогноз пациентов, рефрактерных к блинотумумабу, неутешителен. В этом случае назначение инотузумаба озогамицина является одной из терапевтических опций.

В статье представлено описание клинического случая лечения костномозгового рецидива В-ОЛЛ после гаплоидентичной алло-ТГСК у молодого мужчины. После курса терапии Блинатумомабом ремиссия не была достигнута и пациенту был назначен инотузумаба озогамицин. После одного курса терапии была получена морфологическая ремиссия без признаков минимальной остаточной болезни. Пациенту была выполнена вторая алло-ТГСК от другого гаплоидентичного донора.

\section{Заключение}

Представленный клинический случай демонстрирует успешный исход терапии инотузумаба озогамицином после рефрактерности к блинотумомабу при возникновении рецидива после алло-ТГСК.

\section{Ключевые слова}

Трансплантация гемопоэтических стволовых клеток, аллогенная, острый лимфобластный лейкоз, блинотумомаб, инотузумаб озогамицин, резистентный рецидив. 